\title{
SEJARAH DAN MAKNA FOTOGRAFI KARYA PELUKIS ISTANA, DULLAH
}

\author{
Mikke Susanto \\ Program Studi Tata Kelola Seni, Fakultas Seni Rupa, ISI Yogyakarta \\ Jalan Parangtritis Km 6,5 Sewon, Bantul, DIY \\ No. HP.: 089651318766,E-mail: susantomikke@gmail.com \\ Irwandi \\ Program Studi Fotografi, Fakultas Seni Media Rekam, ISI Yogyakarta \\ Jalan Parangtritis Km 6,5 Sewon, Bantul, DIY \\ No.HP.:081328656252,E-mail: insinyurwandi@gmail.com
}

\begin{abstract}
ABSTRAK
Eksistensi pelukis Dullah sejajar dengan pelukis ternama lain, seperti Affandi, Basoeki Abdullah, S. Soedjojono, dan Hendra Gunawan. Pada tahun 1950 hingga 1960, ia ditunjuk Presiden Sukarno sebagai pelukis istana. Selain melukis, ia juga hobi memotret dengan objek sekitar pekerjaannya sebagai pelukis istana dan figur Presiden Sukarno. Setelah dikaji dari pendekatan sejarah dan digali makna di dalamnya, foto-foto tersebut memiliki simpul menarik. Foto-foto tersebut menyimpan narasi penting, khususnya dalam bidang sejarah bagi bangsa Indonesia. Fotografi Dullah mampu merekam kehidupan Presiden Sukarno pada saat di istana dan di luar istana presiden. Sisi kemanusiaan Sukarno digambarkan dalam foto-foto tersebut, baik sebagai ayah, pemimpin, maupun penyuka seni. Dengan mengetahui simpul tersebut, foto-foto karya Dullah ini perlu disosialisasikan kepada publik dan dapat digunakan sebagai sarana pendidikan kebangsaan bagi Indonesia, terutama bagi para calon pemimpin.
\end{abstract}

Kata kunci: fotografi, Dullah, Sukarno, istana presiden

\begin{abstract}
History and Meaning of Photography of a Palace Painter, Dullah. The existence of Dullah the painter is equal with other famous painters, such as Affandi, Basoeki Abdullah, S. Soedjojono and Hendra Gunawan. In 1950 to 1960, he was appointed by President Sukarno as a palace painter. Apart from painting, he also liked to take pictures. His object was around his work as a palace painter and President Sukarno's figure. Reviewed from the historical approach and the meaning explored in it, the photos have an interesting connection. Those photos hold important narratives, especially in the field of history for the Indonesian people. Dullah's photography was able to record the life of President Sukarno while at the palace and outside the presidential palace. The photos clearly illustrate the human side of Sukarno, as a father, a leader, and an art lover. By knowing the connection,, photographs of Dullah's work need to be socialized to the public and can be used as a means of national education for Indonesia, especially for prospective leaders.
\end{abstract}

Keywords: photography, Dullah, Sukarno, presidential palace 


\section{PENDAHULUAN}

Sepanjang tahun antara 2009 hingga 2019 riset tentang koleksi benda seni koleksi Presiden Sukarno telah dikerjakan. Riset tersebut dilakukan di berbagai tempat, baik di ruang seni maupun nonseni. Riset dilakukan mulai di studio para seniman, keluarga atau ahli waris, lembaga negara dan swasta, hingga ke sejumlah museum. Pada saat riset dilakukan tersebut, penulis mendapatkan ratusan foto tentang keseharian Presiden Sukarno. Di antara foto-foto tersebut salah satunya dibuat oleh pelukis istana, Dullah.

Penemuan fotografi karya pelukis asal Solo ini melatarbelakangi ide untuk meriset lebih lanjut. Selain foto-foto tersebut belum pernah dilihat banyak orang, juga menyimpan narasi kisah yang luar biasa. Keluarbiasaan itu terletak pada kisah yang tertera di dalamnya. Objeknya mengetengahkan kehidupan sehari-hari sejumlah tokoh utama di kompleks yang amat penting bagi bangsa ini: Istana Kepresidenan Republik Indonesia.

Foto-foto yang didapatkan tersebut lalu disalin dalam format digital atas sepengetahuan dan seizin keluarga Dullah. Dengan format digital, penyimpanan dan pelestarian foto dapat dilakukan lebih baik, mudah, dan aman. Foto-foto yang telah disalin tersebut kini tersimpan di Dicti Art Laboratory Yogyakarta. Dicti Art Laboratory adalah lembaga mitra budaya yang bergerak dan menjadi bagian kerja kesenian dan seniman, utamanya sebagai laboratorium kajian seni rupa. Visi yang diemban adalah mendukung dan menggerakkan berbagai program seni sebagai bagian dari kehidupan bermasyarakat. Program-program yang terkait antara lain adalah penelitian, pelestarian, pengurasian, pengelolaan seni, pengarsipan, dan penerbitan buku. Lembaga ini didirikan oleh Mikke Susanto dan Rina Kurniyati pada 2010-2011 sebagai bentuk kepedulian akan kurangnya infrastruktur seni, terutama lembaga arsip seni rupa yang ada di Indonesia. Di lembaga ini tersimpan ribuan katalog pameran seni, kliping media massa, poster pameran, buku-buku seni, sejarah dan budaya, hingga koleksi benda seni rupa, khususnya dari Indonesia. Dari ratusan foto tersebut lalu dikembangkan berbagai program sosialisasi, antara lain melalui pameran dan penulisan artikel dan buku.

Sejumlah pameran yang menggunakan fotografi Dullah adalah Pameran Koleksi Istana Kepresidenan Republik Indonesia “17/71: Goresan Juang Kemerdekaan" di Galeri Nasional Indonesia Jakarta, Pameran Fotografi "Sukarno, Pemuda dan Seni" di Jogja Gallery, dan Pameran "Art \& Diplomacy" di Perpustakaan Nasional Indonesia, Galeri Fotografi Jurnalistik Antara Jakarta, dan Museum Bronbeek Arnheim Belanda.

Adapun tulisan ilimah yang turut didukung dengan foto-foto Dullah adalah: (1) Mikke Susanto, Bung Karno Kolektor \& Patron Seni Rupa Indonesia (2014); (2) Mikke Susanto dan Agus Dermawan T., 17/71, Goresan Juang Kemerdakaan (2016); (3) Sri Margana dan Mikke Susanto, Sukarno Pemuda dan Seni (2017); (4) Mikke Susanto, Sukarno Favourite Painters (2018); dan (5) Mikke Susanto, "Curating the Painting Collection of the Presidential Palace of the Republic of Indonesia", Jurnal Seni Internasional LEKESAN, Volume I No. 1, April 2018, E-ISSN: 2598-2192, Penerbit ISI Denpasar. Berbagai arsip tersebut menjadi sarana agar publik mendapat informasi secara langsung, mudah, sekaligus estetik.

Tentu saja kebiasaan Dullah dalam memotret tidak bisa atau tidak mudah dilakukan oleh setiap orang atau fotografer pada saat itu. Dengan melihat latar belakang Dullah, pembaca akan menemukan sebab-musabab tentang lahirnya foto-foto tersebut. Inilah salah satu tujuan artikel ini dikerjakan. Selain tujuan lain yang juga penting, yaitu melacak bagaimana seorang presiden dan hal-hal atau rekanrekan yang difotonya hidup di dalam istana dan di luar istana. Tujuan riset ini juga untuk mengetahui upaya pendokumentasian seorang pelukis istana karena tugas ini sekarang tidak lagi eksis. Tujuan terakhir yang ingin disajikan adalah untuk menelisik fungsi fotografi Dullah dalam berbagai bidang studi budaya, khususnya sejarah.

Berdasarkan beberapa tujuan yang telah dikemukakan, rumusan masalah yang ingin 
diketengahkan adalah bagaimana sejarah dan makna fotografi karya Dullah.

Secara teoretis, dalam konteks profesi, fotografer memiliki fungsi, tugas, dan eksistensi yang unik. Ia adalah profesi yang tidak saja menyenangkan bagi sebagian orang, tetapi juga penting bagi peradaban. Seturut pendapat Vilem Flusser, fotografer bisa dikatakan tidak bekerja, namun melakukan sesuatu. Mereka membuat, memproses, dan menyimpan simbol. Sebenarnya banyak yang melakukan hal ini, seperti halnya profesi pelukis, komposer, manajer, dan penulis. Mereka menghasilkan objek berupa buku, lukisan, neraca, rencana, yang mungkin tidak dikoleksi, namun lebih berfungsi sebagai pembawa informasi. Karya mereka dibaca, dilihat, dimainkan, diperhitungkan, dan digunakan sebagai dasar keputusan (Flusser, 2000:25).

Untuk mengatur kebutuhan memotret, baik dalam aspek artistik, ilmiah, maupun politis, fotografer memiliki konsep tertentu yang dapat dikaitkan di dalamnya. Flusser menyatakan bahwa tidak ada yang namanya konsep naïf, bodoh, atau fotografi nonkonsep. Semua foto adalah gambar konsep. Dalam hal ini, semua kriteria yang diinginkan fotografer termuat dalam karyakaryanya (Flusser, 2000:36). Jika mereka melihat dunia melalui kamera, ini bukan karena dunia menarik minat mereka, tetapi lebih karena mereka sedang mengejar kemungkinan baru menghasilkan informasi dan mengevaluasinya (Flusser, 2000:26).

Adapun niat fotografer dalam berkarya setidaknya dapat dilihat dari fungsi dasar, yaitu: (1) memberi kode dunia ke dalam gambar; (2) sengaja melakukannya dengan kamera, (3) untuk menunjukkan gambar yang dihasilkan kepada orang lain sebagai model pengalaman, pengetahuan, penilaian, dan tindakan mereka; dan (4) untuk membuat model-model di atas secara permanen. Singkatnya, niat fotografer bekerja adalah untuk memberi tahu orang lain melalui foto untuk mengabadikan diri atau sesuatu dalam ingatan orang lain (Flusser, 2000:45-46). Jika fotografi dinilai sebagai sebuah objek, sebagai sesuatu yang fisikal tanpa disertai nilai apa-apa, tak lebih dari selebaran biasa. Dengan demikian, fotografi merupakan media untuk memindahkan jejak memori, merekam, sekaligus merefleksikan realita, dan media representasi yang penting untuk mengabadikan suatu peristiwa yang telah berlangsung pada masa lalu, secara apa adanya dengan sangat sempurna (Rusli, 2018:2).

Semua hal yang diungkapkan di atas merupakan kajian teoretis yang memayungi peran Dullah sebagai fotografer beserta fungsi yang mengikutinya. Adapun kajian khusus yang terkait dengan posisi Dullah dalam peta perkembangan seni, secara khusus dalam buku Dullah Raja Realisme Indonesia (Sudarmaji, 1988). Buku ini menjadi satu-satunya yang mengisahkan sejarah hidup Dullah, dan buku ini dikerjakan semasa Dullah masih hidup. Buku ini menjadi pijakan kisah yang paling otentik selama ini, meskipun hanya sedikit yang menceritakan perihal kebiasaan memotretnya.

Artikel ini mengajak pembaca untuk mengkaji fotografi Dullah melalui pendekatan historiografi dan visual. Dengan pendekatan historiografi diharapkan pembaca mendapatkan informasi yang sahih dan dapat dipertanggungjawabkan. Adapun pendekatan visual, ditelaah dari objek atau topik yang diketengahkan dalam karya fotografi Dullah tersebut.

Untuk mencapai tujuan tersebut, konsep gramatika visual digunakan dalam membahas foto-foto Dullah. Tujuannya untuk memaknai sejumlah citra yang hadir di dalamnya. Kress \& Leeuwen (2006:1-15) menawarkan satu pendekatan untuk membaca benda-benda visual (termasuk fotografi) yang mereka sebut gramatika visual. Kress dan Leeuwen menyatakan penggunaan istilah grammar (tata bahasa) mengarah pada kaidah, atau dapat diartikan sebagai kaidah-kaidah yang umum digunakan. Maksud Kress dan Leeuwen tentang gramatika dalam konteks ini ialah kaidah yang berada dalam wujud kesadaran kolektif dan pendayagunaan sebentuk sumber daya dalam praktik kehidupan sehari-hari. Sementara itu, kata visual mengarah ke generalisasi untuk mencakup berbagai 
jenis wacana gambar seperti lukisan, komik, ataupun film. Dengan demikian, dua poin yang dinyatakan oleh Kress dan Leeuwen mengisyaratkan bahwa gramatika visual merupakan kaidah-kaidah dalam memanfaatkan berbagai sumber daya yang lazim digunakan dan berlaku secara sosial/kolektif dalam praktik visualisasi.

Secara ringkas dapat dikatakan, gramatika visual digunakan untuk mewujudkan sebuah pernyataan visual yang utuh dan bermakna. Cara pembacaan imaji yang dirumuskan oleh Kress dan Leeuwen (2006:15) menganalogikan benda visual sebagai bentuk bahasa yang memiliki kaidah khusus sehingga berbeda dengan struktur gramatik pada bahasa verbal.

Lebih spesifik, akan dibahas penerapan porsi bingkai dalam kaitannya dengan jarak sosial antara gambar dan pemirsa foto. Pembingkaian, yang secara visual membentuk proporsi ukuran objek foto yang tergambarkan terhadap bidang yang ditempati, turut memengaruhi jarak sosialnya dengan pemirsa. Sejalan dengan itu, dalam tata pengambilan gambar dikenal beberapa istilah khusus yang sering digunakan, antara lain close up, medium shot, dan long shot. Pemilihan tata pengambilan gambar juga akan berimplikasi pada jarak sosial yang terbentuk antara peduduk dan pemirsa. Pengambilan secara close up akan membentuk interaksi yang akrab dan intim. Pengambilan secara medium shot akan membentuk interaksi yang wajar dan tidak intim. Yang terakhir, pengambilan gambar secara long shot akan menimbulkan kesan berjarak sehingga keterlibatan pemirsa tidak terasa.

Sebuah citra, yang di dalamnya terdapat orang atau sesuatu yang dapat di-“orang"-kan sedang melihat ke arah tertentu, maka akan menghasilkan tatapan/laku pandang (gaze). Orang atau sesuatu yang di-“orang"-kan dalam sebuah benda visual oleh Kress dan Leeuwen disebut partisipan yang ditampilkan (represented participant). Dalam konteks foto potret, partisipan yang ditampilkan tidak lain ialah subjek foto potret. Arah tatapan subjek foto akan memengaruhi bentuk keterlibatan pemirsa. Tatapan langsung ke arah pemirsa akan menghasilkan laku pencitraan (image act) yang memberi pesan ajakan langsung kepada pemirsa untuk terlibat atau melakukan sesuatu. Citra semacam itu oleh Kress dan Leeuwen disebut citra yang meminta (demand), sedangkan untuk citra yang di dalamnya terdapat penduduk menatap ke arah selain kamera, maka bentuk interaksinya akan berbeda, yaitu ajakan tidak langsung. Di sini pemirsa menjadi subjek yang melihat. Apa yang ada dalam sebuah citra menjadi informasi bagi pemirsa, sebagaimana pernyataan Kress dan Leeuwen,

"as items of information,objects of contemplation, impersonally, as though they were specimens in a display case as items of information, objects of contemplation, impersonally, as though they were specimens in a display case" (Kress \& Leeuwen, 2006:119).

Setelah mengetahui tujuan, landasan teori, dan metode riset, dihasilkan simpulan, yang diharapkan dapat menopang kontribusi penelitian ini terhadap objek yang diteliti. Kontribusi penelitian ini akan mengarah pada kepentingan sejarah bangsa yang hingga kini masih perlu dikaji lebih lanjut. Dengan menggali aspek sejarah dan visual, dimungkinkan fotografi karya Dullah ini dapat disejajarkan dengan foto-foto sejarah lainnya yang telah ada.

\section{PEMBAHASAN}

\section{Dullah dan Fotografi}

Sejarah hidup Dullah layak dikatakan sebagai kisah sastra. Ia lahir di Surakarta, 19 September 1919 dari pasangan Bapak Susilo Darso (Darsohatmodjo) dan Ibu Kati. Ia merupakan sulung dari empat bersaudara. Pada masa kanak-kanak, kegemarannya menggambar sudah muncul. Keluarga tentu sangat mendukungnya. Keberadaan ekonomi orang tua dan lingkungan rumah yang kondusif turut memberinya spirit dalam melampiaskan kegemarannya tersebut. Usaha batik orang tua Dullah adalah pemicu lahirnya bakat serta kondusifnya tumbuh kembang kemampuan seninya tersebut. Kemampuan melukis Dullah sejak masa kanak-kanak lalu dilanjutkan dengan keinginan yang keras hingga mencapai citacitanya sebagai pelukis paling hebat dan teratas (Sudarmaji, 1988). 
Dalam konteks perkembangan seni rupa, Dullah akhirnya dinilai sebagai seorang pelukis yang berhasil mewujudkan pemikiran dan gaya pribadi yang menambah khazanah seni lukis realisme di Indonesia. Di mata para pelukis lain, Dullah berada posisi yang tidak menjadi pengikut siapa pun, meskipun berguru kepada para pelukis besar Indonesia bergaya realistik dan naturalistik kala itu, seperti Ernst Dezentje, S. Sudjojono, Affandi, dan Basoeki Abdullah. Terkait dengan ide dan aliran realismenya, Dullah sering kali mengatakan sebagai berikut.

Saya tidak pernah melukis dengan cara imajiner. Maksud saya kita nglukis dengan ngawang, lantas kita nggambar menurut apa yang saya angan-anganken, itu (saya) nggak pernah. Jadi saya anggap ya lebih baik (melukis) yang logis saja!" Begitu kesaksiannya dalam sebuah rekaman film dokumenter pada 1980.

Pada tahun 1942 ia melarikan diri dari Solo ke Jakarta karena menjadi intenir Jepang. Di Jakarta ia tinggal di rumah kakak angkatnya yang bernama Mbakyu Is, di kawasan Kepuh Dalam. Kakak angkatnya itulah yang mengenalkan Dullah kepada Sudjojono yang tinggal di Sunter, Affandi di Jalan Jawa, dan Bung Karno yang tinggal di Pegangsaan Timur. Aktivitas formalnya adalah bergabung di Poetera (Pusat Tenaga Rakjat) pimpinan Sukarno, Hatta, Ki Hadjar Dewantara, dan K.H. Mas Mansyur. Atas keinginan Sukarno, Dullah ditarik ke bagian kebudayaan Poetera. Kepada Sukarno, Dullah pernah bertutur bahwa ia tidak bisa kerja dengan Jepang karena selalu dipenjara dan dicaricari. Bung Karno lalu menjawab,

"Kamu bukan ikut Jepang. Kamu ikut saya. Semua urusanmu dengan Jepang, kalau ada apa-apa, saya yang tanggung. Tetapi kamu jangan berbuat sesuatu di luar pengetahuan saya." (Susanto, 2014:282)

Sejak itulah, Dullah menetap di Jakarta sebagai pelukis. Hari-harinya diisi dengan ragam pekerjaan yang terkait dengan seni. Sampai pada saat setelah proklamasi kemerdekaan didengungkan oleh Sukarno dan Hatta, Dullah mendapati kenyataan, ia harus pindah ke Yogyakarta bersama Presiden
Sukarno beserta rombongan dikarenakan kondisi Jakarta tidak kondusif sebagai ibukota. Sejak Januari 1946 akhirnya Dullah tinggal di Yogyakarta. Selama di Yogyakarta ia bersama-sama pelukis lain bergabung dalam Seniman Indonesia Muda (SIM) pimpinan S. Sudjojono. Di kelompok inilah Dullah aktif berkarya, mengajar seni lukis kepada anakanak, serta mengurus sanggar sebagai sekretaris.

Tepat pada tahun 1949, menjelang Sukarno berangkat dari Yogyakarta ke Jakarta untuk menunaikan tugas sebagai Presiden Republik Indonesia Serikat (RIS), Dullah diminta untuk menemaninya sebagai pelukis istana. Semula tawaran menjadi pelukis istana dari Sukarno ditolak oleh Dullah. Penolakan ini kemudian sirna karena S. Sudjojono mendesaknya. "Kasihan Bung Karno, nanti ia kesepian lantaran tak ada seniman yang bisa diajak omong-omong," ujar mereka seperti dikutip Dullah di Kompas (Sawega, n.d.). Akhirnya diterimalah tugas sebagai pelukis istana. Sejak awal 1950, Dullah tinggal di Istana Presiden di Jakarta.

Sebagai pelukis yang mendampingi Bung Karno selama menjadi presiden tentu saja membuat Dullah harus bersedia kehilangan waktu pribadinya. Setiap hari ia patuh sebagai pegawai istana. Pekerjaannya adalah mengurus koleksi lukisan yang saat itu sudah mulai banyak. Tugasnya antara lain mendisplai karya sesuai arahan presiden dan tentu saja tetap harus melukis di dalam istana.

Meskipun mengalami situasi yang tidak cukup baik bagi dirinya sendiri, Dullah merasa bangga bisa begitu dekat dengan Sukarno dan keluarganya. Kesempatan ini tidak saja langka, tetapi juga membuat dirinya menjadi sosok penting dalam pergerakan seni rupa dan politik langsung di internal istana. Di istana ia mendapat tempat tinggal di sebuah ruang kecil di paviliun yang terletak di sebelah timur di halaman istana negara. Dipilihnya ruang tersebut untuk memudahkan jika Bung Karno secara mendadak memanggilnya. 


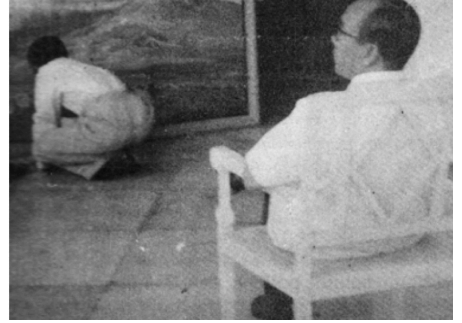

Gambar 1 Presiden Sukarno sedang menunggu Dullah melukis di istana.

(Foto: Koleksi Museum Dullah)

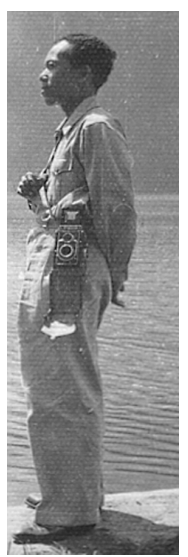

Gambar 2 Dullah dengan jenis kamera TLR Rollei, film 120 pada dekade 1950-an.

(Foto: Koleksi Museum Dullah)

Kegiatan di istana yang cukup menyita waktu menyebabkan Dullah harus selalu sedia diminta tenaganya untuk berbincang mengenai seni rupa dan koleksinya. Perbincangan dan diskusi yang mereka lakukan bisa mengenai fisik lukisan, tema, motif, sampai model lukisan dan memperbaiki lukisan jika ada yang rusak. Menurut Dullah, pembicaraan mengenai seni lukis membuat Sukarno terhibur. Bagi Sukarno, diskusi seni menjadi terapi sekaligus katarsis di tengah persoalan politik yang begitu kompleks. Hubungan mereka sepertinya sudah tidak tanggung-tanggung, kadang-kadang Sukarno langsung ke kamarnya atau untuk beberapa waktu menunggui Dullah melukis. Untuk menjaga agar selalu siap sedia, Dullah sering beristirahat atau tidur siang dengan tetap mengenakan sepatu. Jika dipanggil sewaktu-waktu bisa langsung menghadap presiden.

Dullah selain dipercaya sebagai pelukis, ia juga menjadi fotografer pribadi Sukarno. Belum diketahui apakah Dullah yang diminta memotret oleh Sukarno atau sebaliknya. Bila dicermati saat proses Sukarno membiarkan Dullah memotret dirinya dalam posisi apa pun berarti persetujuan atau izin telah diberikan. Bila dicermati dari hasil foto-fotonya, pekerjaan memotret Dullah ini lebih merupakan kesenangan atau hobi Dullah, bukan perintah resmi dari Sukarno. Terbukti bahwa seluruh foto tersebut masih disimpan secara pribadi oleh (keluarga) Dullah.

Seperti yang diketahui keluarga, kamera yang pernah dipakai Dullah setidaknya ada tiga jenis/ merek: Rollei, Leica, dan Nikon F. Rollei dan Leica dipakai oleh Dullah pada kisaran 1950-an tersebut. Sementara itu, Nikon F dipakainya sejak tahun 1970 hingga 1990. Jika dilihat dari hasil cetakannya, selama memotret di istana, Dullah menggunakan film seluloid $120 \mathrm{~B} \& W$. Foto-foto ini dicetak dalam ukuran sekitar 10x7 cm dan 6x6 cm, cetak hitam putih dengan menggunakan kertas foto yang umum beredar pada saat itu. Foto-foto ini lalu disimpan dalam sebuah album dan diatur sesuai agenda yang dilaksanakan.

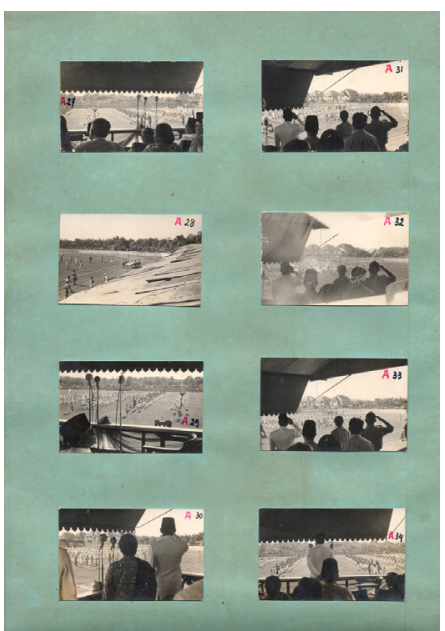

Gambar 3 Salah satu lembar halaman album foto Dullah yang memotret kegiatan Presiden Sukarno. Kemungkinan menggunakan kamera jenis Leica. (Foto: Koleksi Museum Dullah)

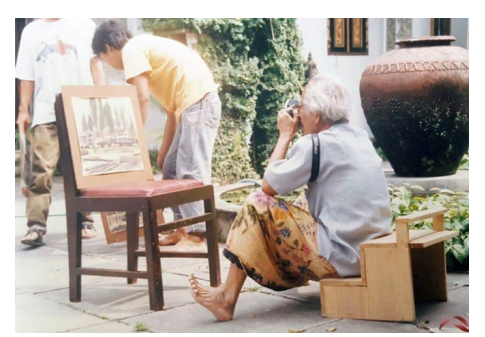

Gambar 4 Dullah saat memotret lukisannya di Museum Dullah Solo dengan menggunakan kamera Nikon F. pada dekade 1990-an.

(Foto: Koleksi Sigit Hendro Sutjahjo (Museum Dullah) 
Kebiasaan memotret Dullah seiring dengan pendapat Flusser yang terkait dengan fungsi dan niatan fotografer yang telah diterangkan dalam pendahuluan artikel ini (Flusser, 2000:45-46). Pemotretan ini terjadi karena Dullah menyadari bahwa ia adalah seseorang yang mendapat tugas penting sebagai staf presiden. Oleh karena itu, ia memanfaatkan keberadaan dan kedekatannya untuk mendokumentasi peristiwa yang dialami bersama Sukarno. Dullah sendiri seperti "bayangan" Sukarno. Ke mana sang Presiden pergi, ia diajak serta dan mengikutinya. Imbas dari "bayangan" tersebut lahirlah ratusan dokumentasi foto yang dikoleksinya sendiri.

Dari sejumlah foto dekade 1950-an yang terdeteksi sampai saat ini, topik yang pernah difoto Dullah antara lain adalah situasi dan kondisi ruang di istana presiden, potret sejumlah staf istana, peringatan hari besar di istana, Presiden Sukarno dan keluarganya, Presiden Sukarno dan para perupa, Presiden Sukarno bekerja di istana, kunjungan Presiden Sukarno ke sejumlah daerah di Indonesia, dan figur yang terkait dengannya sendiri. Kesemua topik tersebut menggambarkan situasi yang berbeda dengan foto-foto resmi kenegaraan yang diemban oleh staf istana presiden. Keseluruhan foto yang dihasilkan Dullah terfokus pada kegiatannya sebagai pelukis istana, yang memiliki tugas membantu presiden dalam semua kegiatan yang berkait dengan seni dan kreativitas.

Sejumlah foto ini lalu difungsikan oleh Dullah dalam beberapa keluaran. Pertama, dipakai untuk menjadi bagian dalam bukunya sendiri yang berjudul Dullah, Raja Realisme Indonesia. Kedua, beberapa di antaranya termuat sebagai ilustrasi dalam esai-esainya di Harian Minggu Merdeka yang dipublikasikan sejak 14 Maret 1982 sampai 22 Mei 1983. Esai-esai ini berkisah tentang kedekatan Dullah dan Sukarno. Ketiga, foto-fotonya juga difungsikan untuk keperluan melukis bagi dirinya sendiri. Keempat, foto-foto tersebut dipublikasikan sebagai citra Sukarno di media massa. Dalam artikel ini disajikan sejumlah presentasi yang sesuai dengan topik yang difotonya.

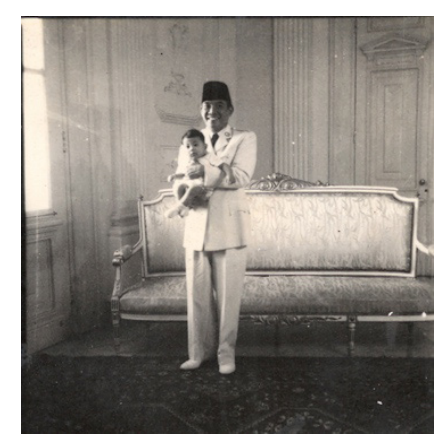

Gambar 5 Presiden Sukarno dan Keluarganya. Sukarno menggendong Guruh Sukarnoputra.

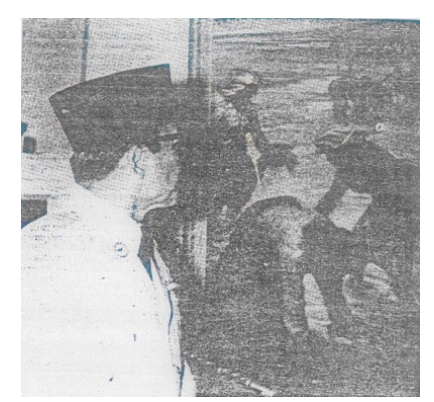

Gambar 6 Presiden Sukarno dan Keluarganya. Sukarno saat menonton lukisan.

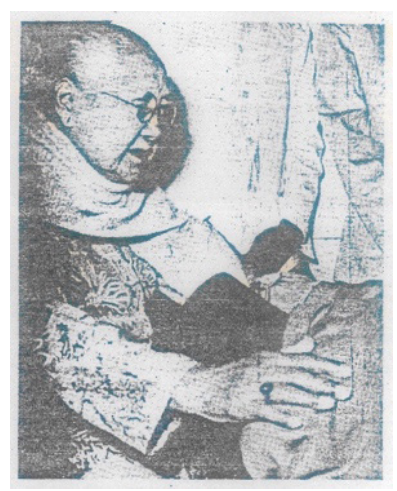

Gambar 7 Presiden Sukarno dan Keluarganya. Sukarno sungkem kepada sang ibu.

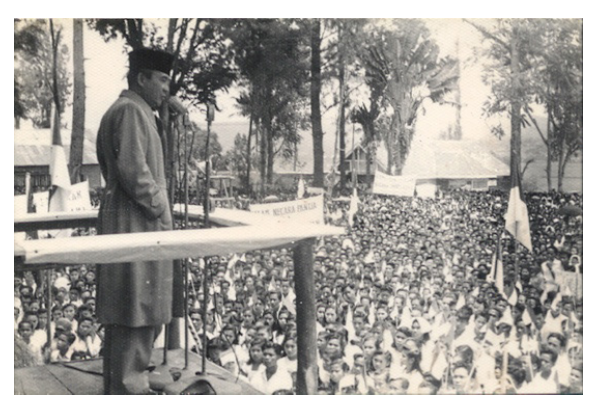

Gambar 8 Potret Presiden Sukarno sebagai Pemimpin. Foto Presiden Sukarno saat pidato. 


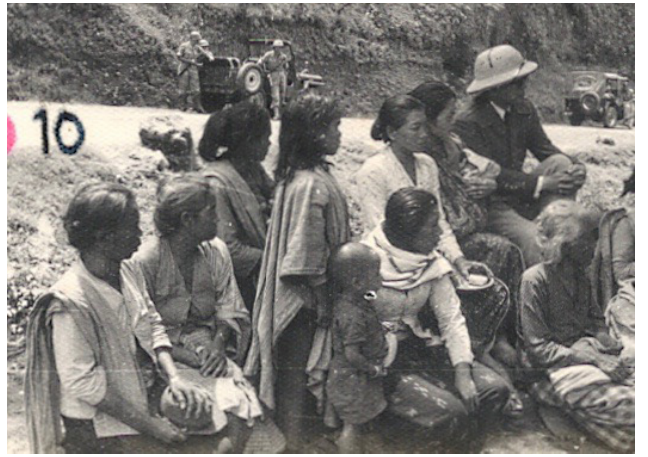

Gambar 9 Potret Presiden Sukarno sebagai Pemimpin. Foto Presiden Sukarno saat berkunjung ke daerah.

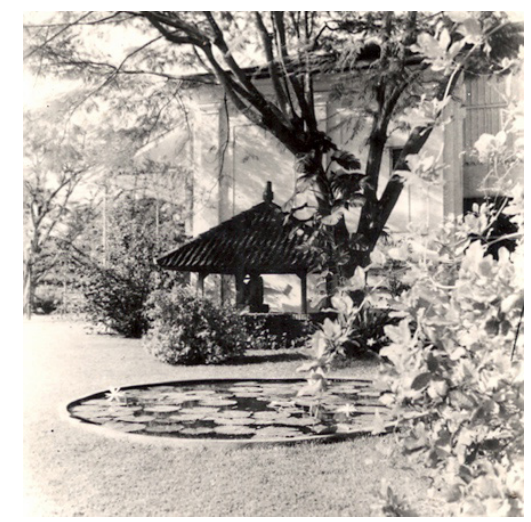

Gambar 10 Halaman Istana Kepresidenan. Kondisi halaman Istana Kepresidenan Jakarta.

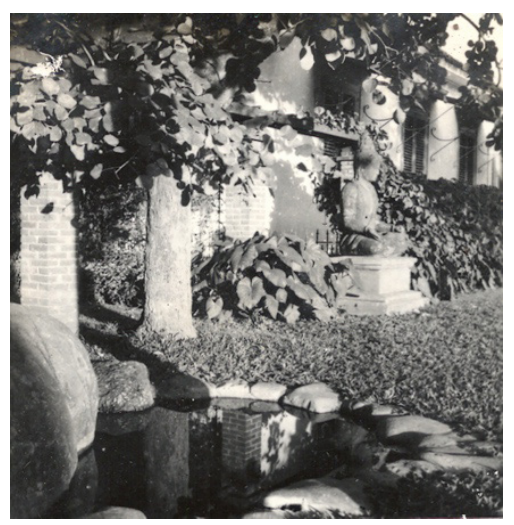

Gambar 11 Halaman Istana Kepresidenan. Kondisi halaman Istana Kepresidenan Jakarta.

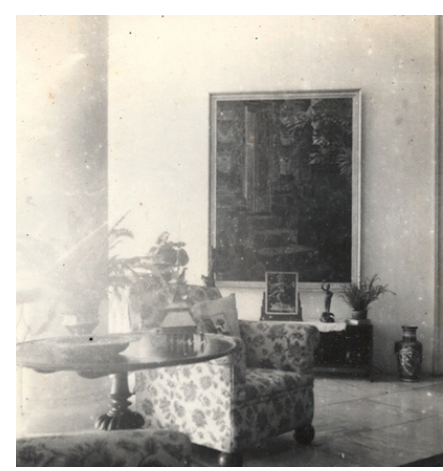

Gambar 12 Interior Istana Kepresidenan. Foto-foto yang menggambarkan situasi dan kondisi ruang dalam istana di Jakarta, baik pada saat sedang ada peringatan hari besar maupun keseharian.

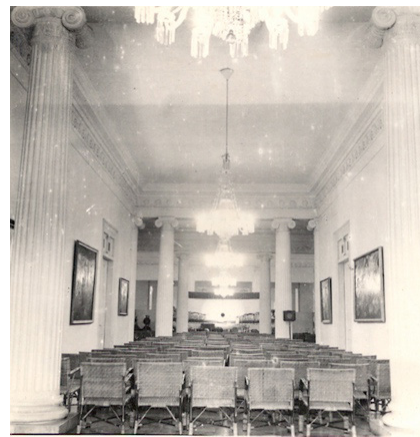

Gambar 13 Interior Istana Kepresidenan. Foto-foto yang menggambarkan situasi dan kondisi ruang dalam istana di Jakarta, baik pada saat sedang ada peringatan hari besar maupun keseharian.

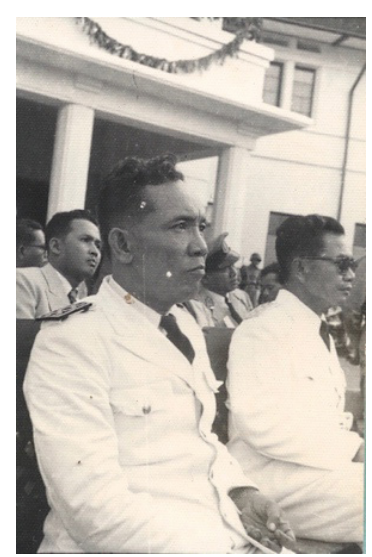

Gambar 14 Potret Figur. Sejumlah potret figur staf istana Letkol (Purn) Sumantri wakil Kepala Rumah Tangga Istana (Kanan) dan kiri Jendral Mayor (Purn) Suhardjo Hardjowardoyo.

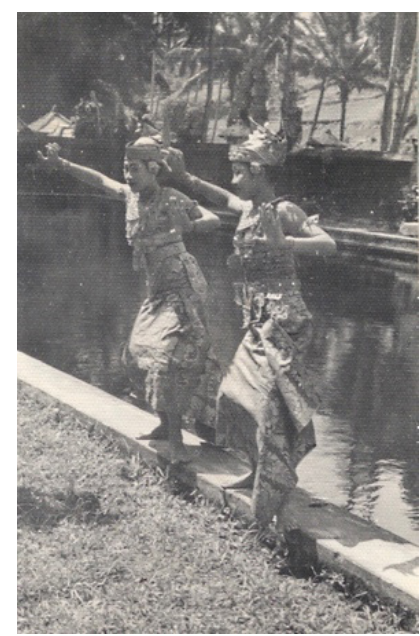

Gambar 15 Potret Figur. Sejumlah potret figur staf istana Kepala Rumah Tangga Istana Jakarta dan foto penari kesayangan Sukarno, Ni Made Darmi.

Selepas tahun 1960 atau saat setelah tidak lagi menjadi pelukis istana, Dullah kemudian bekerja menjadi pelukis profesional. Selama masa antara 1960 hingga akhir hayat pada Januari 1996 Dullah lebih banyak menghabiskan waktunya untuk berkarya seni lukis di luar istana. Setelah 
meninggalkan istana presiden di Jakarta, sejenak tinggal di Solo. Setelah itu, ia tinggal di Bali mendirikan Sanggar Pejeng yang terletak tidak jauh dari Istana Tampaksiring. Selama di Bali ia mengajar murid-muridnya melukis dengan tetap menggunakan pendekatan realisme. Adapun fotografi sesekali juga digunakan olehnya untuk membantu proses pengerjaan melukisnya, meskipun bukan sebagai alat utama. Dullah adalah pelukis lapangan yang sangat ulung. Ia melukis pemandangan alam, potret manusia lebih sering dilukis secara langsung. Kamera foto hanya dipakai untuk hal-hal khusus, misalnya untuk melukis potret istrinya, Fatima atau pesanan potret lainnya, juga untuk momen yang terjadi secara cepat, misalnya panen di sawah dan untuk memotret lukisannya sendiri.

\section{Sukarno dalam Fotografi Dullah}

Problem pengkajian sejarah menjadi agak bermasalah ketika subjek yang tengah diteliti tidak pernah menulis sejarahnya sendiri. Hal ini diakui oleh Daniel Dhakidae yang mengungkapkan bahwa sosok Sukarno tidak punya waktu untuk menulis otobiografinya sendiri (Dhakidae, 2013:4). Karena itulah suasana batinnya tidak bisa diketahui secara umum dan "asli". Ketiadaan sumber utama semacam ini sering kali menjadi problem bagi sejarawan untuk mengetahui secara detail sosok yang sedang diteliti.

Mungkin karena tidak membuat otobiografi, kisah mengenai Sukarno tidak pernah usai dikaji. Sebagai pejuang, pelopor revolusi, dan pemimpin besar ia memiliki kisah hidup yang dinamis sehingga menjadi perhatian banyak peneliti. Tidak kurang, dari peneliti asing seperti Cindy Adams (My Friend the Dictator, 1967 dan Sukarno An Autobiography, as told to Cindy Adams, 1966), Bernard Dahm (Soekarno en de strijd om Indonesië's onafhankelijkheid), J.D. Legge (Soekarno, A Political Biography, 1990), C.L.M. Penders (The Life and Times of Sukarno, 1980), B.B. Hering (Soekarno's Mentjapai Indonesia Merdeka, 1991), Ernst Utrecht (Sukarno-Suharto. Indonesië's dekolonisatie dreigt te mislukken), Paul van Veer
(Soekarno, 1964), Angus McIntyre ("Sukarno as artist-politician" dalam Indonesian Political Biography), hingga buku penting dan gigantis karya Lambert Giebels Giebels (Soekarno, Biografi 1901-1950 dan Pembantaian yang Ditutup-Tutupi: Peristiwa Fatal di Sekitar Kejatuhan Bung Karno) telah mengkaji secara detail dan gamblang. Di luar itu, sejumlah 1190 teks tertulis telah dihasilkan Sukarno sepanjang hayat (Yayasan_Idayu, 1984). Belum lagi buku-buku yang dihasilkan-tetapi bukan biografi--oleh Sukarno sendiri yang tidak memungkinkan disebutkan di sini karena keterbatasan halaman.

Sejumlah buku yang telah disebutkan tersebut rupanya tidak satu pun yang mengungkap keseharian Sukarno di istana secara langsung dan detail. Sejumlah buku tersebut lebih mengungkap masalah dan isu-isu tentang kisah hidup sejak lahir hingga meninggal, pemikiran, dan sejumlah kegiatannya di luar istana. Padahal dekade 1950-1960 merupakan masa Sukarno menjadi aktor utama dalam sejumlah kebijakan dan agenda nasional dan internasional.

Karena itulah, sebagai pembanding sekaligus pendukung dalam memaknai fotografi Dullah digunakan artikel-artikel yang ditulis oleh Dullah di Harian Minggu Merdeka (Dullah, 1982). Artikelartikel ini korelatif dan penting dipakai sebagai dasar dalam melacak sejarah Sukarno saat di istana. Sejumlah 60 artikel Dullah tersebut kini telah dikompilasi oleh Museum Dullah dan Dicti Art Laboratory dengan judul BUNG KARNO: Pemimpin, Presiden, Seniman yang terbit pada bulan November 2019 (Susanto, 2019). Dalam buku tersebut terdeskripsikan ragam kisah Sukarno di istana disertai dengan beberapa foto karya Dullah. Untuk itulah, dalam artikel ini diungkap hubungan antara teks sejarah dan fotografi yang dihasilkan oleh Dullah.

Keseluruhan fotografi karya Dullah dalam buku tersebut terpusat pada sosok Presiden Sukarno. Sejak muda, Sukarno memang sering difoto oleh sejumlah fotografer. Sukarno menyadari bahwa dirinya sebagai subjek sejarah sekaligus objek foto yang penting dalam setiap peristiwa. Seperti yang 
diungkap Oscar Motuloh bahwa Sukarno sadar akan kekuatan fotografi. Misalnya yang terjadi pada tahun 1949, ia menugaskan fotografer Frans Mendur menemani Letkol Suharto dan Rosihan Anwar menjemput Panglima Besar Jenderal Sudirman. Setiba di Istana Presiden Yogyakarta, ia memeluk Sudirman. Malang, momentum tersebut terlalu cepat. "Ya sudah, diulang adegan zoentjesnya," ujar sang Presiden. Maka jadilah foto Sukarno merangkul Jenderal Sudirman, sebagai bukti semua betapa sipil dan militer bersatu (Motuloh \& Surjoatmodjo, 2013:108).

Pada kesempatan ini ditelusuri bagaimana Dullah memotret Sukarno. Dengan berbekal modal atau status sosial yang dimilikinya sebagai pelukis istana, Dullah tentu memiliki cara pandang tersendiri pada sosok presiden yang menjadi atasannya. Untuk itulah, penulis memilih lima foto terkait Sukarno untuk dideskripsikan muatan atau makna yang ada di dalamnya. Semua informasi diperoleh dari tulisan Dullah dalam kompilasi artikel yang sudah disebutkan.

Dalam foto 16, tergambar Sukarno tengah memangku putranya, Guruh Sukarnoputra. Di sebelahnya duduk putra pertamanya, Guntur Sukarnoputra. Foto ini berseting sofa mewah dilatarbelakangi Ruang Kredensialdi Istana Merdeka pada 1953 (Sukarnoputra, 2019). Sepintas foto ini tampak sederhana. Dullah sebagai fotografer sepertinya ingin menunjukkan sisi khusus tentang Sukarno dan keluarga secara semiformal. Foto ini secara gramatis menunjukkan adanya demand dari subjek di dalamnya. Laku pandang para subjek dengan cara menatap kamera membangun interaksi kepada pemirsa. Senyum dan raut muka khas Sukarno tampil dominan walaupun secara ukuran sangat kecil dibandingkan keseluruhan bidang.

Sebagai kepala negara, tentu acara dan agendanya begitu padat. Dalam tulisannya, Dullah justru mengungkapkan bahwa meskipun sibuk, Sukarno masih bisa mengatur waktu di antara kesibukan untuk bertemu dengan anggota keluarganya. Sesudah Ibu Fatmawati tidak tinggal di istana, Sukarno tinggal bersama kelima anak dari Fatmawati: Guntur, Mega, Rachma, Sukma, dan Guruh.

Pada suatu ketika, Dullah berkisah tentang hubungan mereka. Tiap pagi pada saat anak-anak sudah siap berangkat ke sekolah, lebih dulu datang menghampiri Sukarno di beranda belakang Istana Merdeka. Sambil memandang ketiga putrinya menuju ke kendaraan yang akan membawanya ke sekolah, Sukarno berucap, "E, semoga kelak mendapatkan jodoh orang yang bisa momong." Ternyata doa sang ayah lebih kepada orang yang bisa momong atau memerhatikan dan memberi panutan dengan baik, bukan orang kaya atau yang ganteng. Sebab, memberi mendapat suami yang pandai momong adalah kebahagiaan bagi istri. Selain kisah tersebut, Dullah juga menulis bahwa setiap malam Sukarno selalu bangun menengok putra-putrinya yang terlelap. Di sana ia membetulkan letak tidur dan selimut yang barangkali terlepas. Apalagi kalau ada yang sedang sakit, sampai dua tiga kali menengoknya pada waktu malam. Itulah gambaran keseharian Sukarno dengan anak-anaknya yang diwujudkan Dullah dalam foto 16.

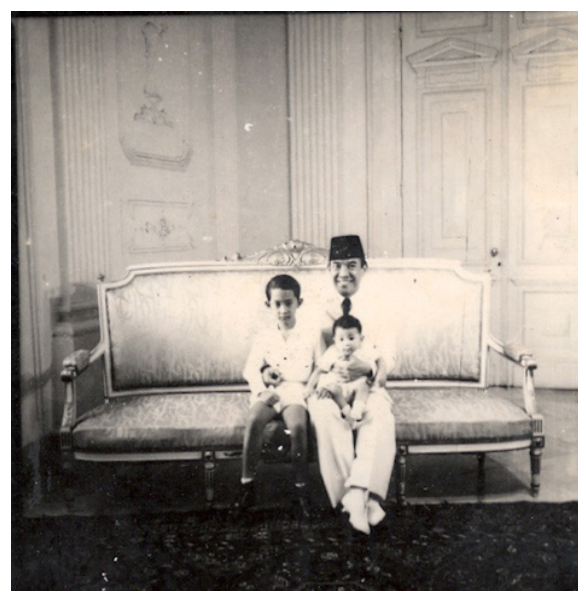

Gambar 16 Foto Dullah berobjek Presiden Sukarno bersama dua putranya. 


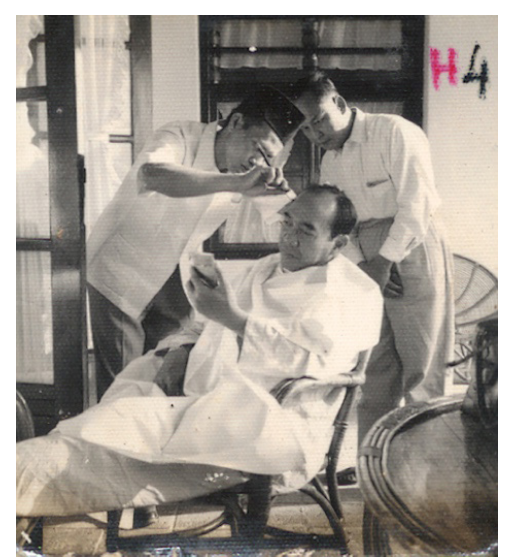

Gambar 17 Foto Dullah menggambarkan Presiden Sukarno tengah dicukur rambutnya.

Foto Dullah dalam gambar 17 menggambarkan Sukarno tengah melakukan aktivitas pribadinya, yakni mencukur rambut. Foto ini tidak dijelaskan secara terperinci oleh Dullah. Berdasarkan wawancara penulis dengan Guruh Sukarnoputra, foto ini merupakan peristiwa saat Sukarno sedang mencukur rambutnya di Istana Presiden Yogyakarta, sekitar tahun 1949 (Sukarnoputra, 2019). Tepatnya setelah pulang dari pengasingannya di Bangka. Dalam tulisannya Dullah menyatakan tukang cukur langganan keluarga bernama Pak Aziz, namun sepengetahuan Guruh, tukang cukur dalam foto ini bukan Aziz. Belum diketahui siapa tukang cukur dalam foto ini.

Secara visual terlihat bahwa ternyata Sukarno lebih senang mengundang tukang cukur, alias tidak mencukur rambut di salon atau datang ke tempat cukur. Tampak salah satu staf istana mendampingi dan mengawasinya, yaitu Pak Tukimin (Kepala Kerumahtanggaan Istana). Proses mencukurnya pun manual, dari penggunaan kursi rotan sederhana yang pendek (bukan kursi untuk mencukur) sehingga tukang cukurnya harus lebih merendahkan tubuhnya, kain putih untuk menghindari rambut masuk ke dalam baju atau tubuh, hingga menggunakan cermin berukuran kecil yang dipegang sendiri oleh Sukarno untuk mengawasi guntingan pencukur.

Hal menarik lain dalam foto ini adalah hanya tukang cukur sajalah yang bisa dan berani memegang kepala presiden dengan leluasa. Dalam gambar 17 Dullah seperti ingin menunjukkan kepada penonton bahwa Sukarno tidak memiliki kebiasaan bercukur yang canggih dan mahal, semua dilakukan secara sederhana. Dullah ingin mengungkapkan sisi manusiawi seorang presiden dalam hal penampilan. Ternyata kebiasaan yang dilakukan Sukarno sama seperti kebanyakan orang.

Laku pandang Sukarno dalam foto ini tidak menghadap kamera. Ia tampak sedang menatap ke cermin kecil yang ia pegang. Hal yang sama juga tampak pada pose juru cukur dan pengawal Sukarno. Citra seperti ini dalam konteks gramatika visual ialah citra yang offer (menawarkan). Sukarno dalam citra ini tidak membangun keterlibatan secara langsung, namun lebih menyediakan informasi kepada pemirsa. Sukarno bersama juru cukur dan pengawalnya menjadi objek amatan utama dalam citra ini.

Gambar ke-18 memperlihatkan sosok Sukarno tengah berpidato. Menurut Dullah, sebagai orator yang baik, Sukarno memiliki modal yang cukup, yakni pengetahuan yang luas, kecerdasan yang tinggi, ingatan yang tajam dan kuat, badan yang tinggi tegap, dan wajah menarik dengan sorot mata yang tajam. Sebelum pidato Sukarno biasanya minum seteguk air putih. Biasanya disediakan oleh stafnya sendiri bernama Pak Tukimin. Selain itu, Sukarno tidak suka berpidato di mimbar berbentuk kotak yang mengurung tubuhnya sampai sebatas dada. Ia merasa hal itu sangat mengurangi kebebasan dalam menggerakkan tangan untuk membantu memberikan tekanan dan kemantapan pada kata-katanya.

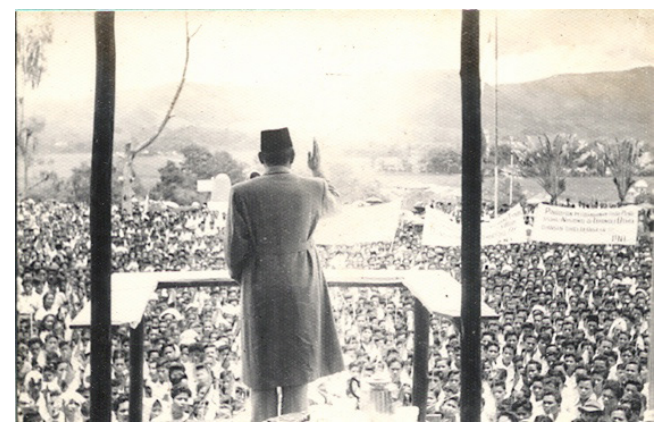

Gambar 18 Foto Dullah yang menggambarkan Presiden Sukarno tengah pidato 


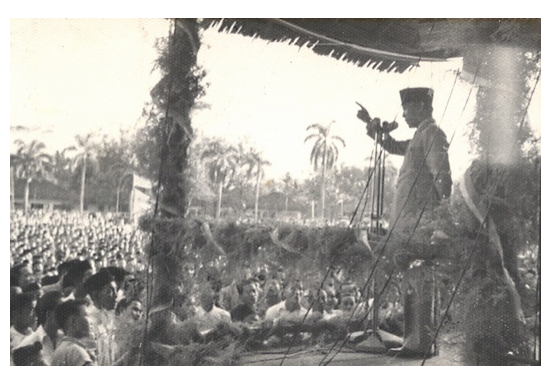

Gambar 19 Foto Dullah saat Presiden Sukarno di depan pelantang.

Mula-mula, sesudah Sukarno naik panggung seluruh pandangannya dilepaskan ke pengunjung. Kadang-kadang sambil tangan kirinya mengambil saputangan yang ada di dalam kantong celana dengan maksud memperpanjang waktu. Di luar itu, terkadang Sukarno juga meminta semua bendera yang dibawa dalam rapat-rapat raksasa yang nampak menjulang digulung agar tidak mengganggu atau menghalangi pandangan orang yang ada di belakang bendera.

Apabila Sukarno sudah siap di atas podium, tetapi massa masih belum juga tenang, di sana-sini masih terdengar suara-suara berisik, Sukarno lalu berkata, "Diaaam, diaaam...!!!" teriaknya di depan pelantang. Seketika itu semua akan diam dan Sukarno mulai berpidato. Sering kali bila usai pidato, rakyat masih ingin agar Sukarno melanjutkan, hingga suasana riuh sekali. Untuk menenteramkan suasana, Sukarno memiliki cara sendiri, yakni mengajak massa menyanyi bersama-sama. Inilah sejumlah hal yang mungkin belum disadari atau diketahui publik, terkait dengan kebiasaan Sukarno dalam berpidato.

Foto ini dipakai oleh Dullah untuk menerangkan perihal penggunaan pelantang saat Sukarno berpidato. Bagi Sukarno, peranan pelantang sangat penting, seperti sebuah instrumen yang membawa suaranya sampai di titik yang terjauh. Sukarno tahu benar cara menggunakan pelantang. Ia menengok ke kiri, badannya digerakkan menggeser sedikit ke kanan. Begitu pula sebaliknya. Tujuannya agar suara tetap tepat masuk ke mulut pelantang. Bila suara tersebut tidak masuk ke mulut pelantang, akibatnya suaranya terdengar lirih atau sama sekali tidak terdengar, hingga pidatonya terasa putus.
Persoalan ini bagi Dullah penting dan terkait dengan urusan pekerjaan. Kemahiran pidato Sukarno menyebabkan ada orang yang mengatakan bahwa Sukarno ingin selalu menjadi yang paling menonjol, yang paling terlihat, dan yang paling diperhatikan. Andaikata ini benar, tentu ini akibat "pekerjaan" Sukarno sebagai ahli pidato. Seandainya bukan Sukarno, apakah kira-kira kebiasaan hidup orang lain juga berubah atau terpengaruh oleh "pekerjaan" bernama pidato?

Dalam foto 20-21 kisahnya lain lagi. Dalam foto ini tampak Sukarno sedang dipeluk oleh/dan memeluk seorang ibu tua. Di belakangnya terdapat dua orang pengawal presiden. Sayangnya, kedua foto ini tidak ada keterangan lokasi dan waktu. Foto ini secara sepintas menandai peristiwa seorang presiden yang dekat dengan rakyat. Beberapa kali, Dullah mengisahkan bahwa Sukarno sering keluar istana melihat kehidupan rakyat kecil di kampungkampung. Sukarno sering ke kampung, baik saat di Jakarta maupun di Bali dan di sejumlah daerah lainnya di Indonesia.

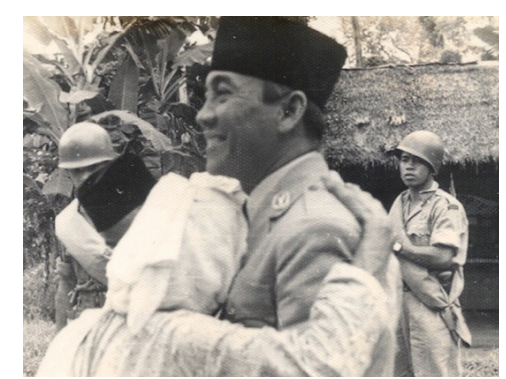

Gambar 20 Foto karya Dullah yang memotret Presiden Sukarno bersama rakyat.

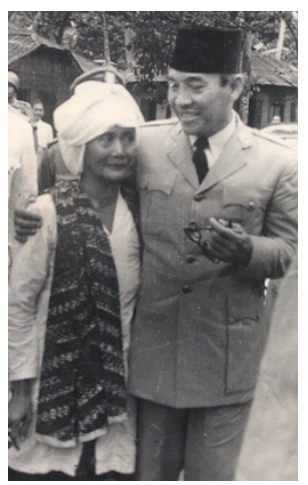

Gambar 21 Foto karya Dullah yang memotret Presiden Sukarno bersama rakyat. 
Setiap presiden berkunjung ke daerah, rakyat selalu mengelu-elukan dan menyambutnya dengan gegap gempita. Sepanjang jalan dan di muka rumah bendera dikibarkan, diselingi umbul-umbul. Rakyat sudah berjam-jam berdiri berderet rapat sepanjang jalan menyambutnya dengan melambai-lambaikan tangan dan meneriakkan "Hidup Bung Karno". Tidak jarang rakyat yang berkumpul di tepi jalan menyerbu ke tengah jalan menghentikan iringiringan kendaraan rombongan Presiden meminta agar Sukarno turun. Rakyat dengan begitu merasa puas terpenuhi keinginannya dapat melihat wajah presidennya dengan jelas.

Dullah menyatakan bahwa motivasi rakyat mencintai Sukarno tidak bisa dijawab dengan mudah. Lalu Dullah memberi jawaban tentang kecintaan rakyat kepada Sukarno lebih didasarkan karena pengabdian Sukarno kepada bangsa Indonesia sangat besar. Sejak masih muda hingga menjalani pembuangan, lalu sampai pada saat ia menjadi presiden telah ditempa oleh berbagai ujian hidup untuk memerdekakan dan membuat bangsa Indonesia menjadi negara besar. Masih menurut Dullah, kecuali alasan tersebut, rakyat juga merasa bahwa Sukarno telah berhasil malik grembyang (berhasil membalik dengan mudah) mental rakyat Indonesia yang berjuta-juta dari mental budak menjadi mental berdikari sebagai bangsa merdeka yang sadar akan hak dan kewajibannya. Dengan demikian, dari dua foto ini pembaca dapat merasakan kecintaan rakyat terhadap Sukarno.

Dalam dua foto tersebut Dullah ingin menunjukkan bahwa seorang Sukarno yang telah menjalani ujian hidup sedemikian rupa menjadi amat terhibur karena dekat dengan rakyatnya. Kedekatan dengan rakyat telah menjadi bagian hidup yang penting bagi Sukarno. Dullah menunjukkan perkataan Sukarno yang diingatnya, bahwa cinta yang dibarengi dengan rasa kasihan adalah cinta yang kokoh tak tergoyahkan. Begitu pula bagi siapa saja dalam hatinya benar-benar menaruh iba dan kasihan terhadap rakyat kecil yang nasibnya masih serba kekurangan, cinta mereka tidak akan tergoyahkan.

\section{SIMPULAN}

Itulah sejumlah gambaran dan makna terkait antara Dullah dan Presiden Sukarno, yang dirangkum melalui karya fotografi. Ratusan foto karya Dullah yang kini masih tersimpan rapi bila dikaji secara mendalam akan memberikan makna yang luar biasa. Makna dari sejumlah foto ini akan memberi kesan terhadap seseorang atau tentang sesuatu. Fotografi telah memberi jawaban terhadap berbagai hal yang sementara ini belum terungkap dalam sejarah. Fotografi telah membantu bidang studi sejarah untuk memvisualisasikan berbagai kejadian masa lampau.

Di luar persoalan sejarah dan makna fotografi karya Dullah, secara umum hasil kerja Dullah ini dapat dianggap sebagai sebagai warisan budaya yang penting. Dengan mengikuti teori yang diusung oleh Flusser bahwa fotografer telah membuat, memproses, dan menyimpan simbol, dapat disimpulkan bahwa Dullah juga melakukan kerja simbolik. Foto-fotonya menyimpan makna yang tidak saja terkait dengan Sukarno, namun juga pada hal-hal lain yang kini belum terungkap. Secara kodratnya sebagai alat perekam, fotografi memiliki hubungan yang dekat dengan keseharian dan perkembangan kehidupan sosial budaya dalam masyarakat (Ismanto, 2018:70).

Selain sebagai sumber sejarah, fotografi Dullah dapat diangkat sebagai karya seni karena juga menyimpan simbol-simbol yang bisa dimaknai lebih lanjut. Dullah yang berprofesi sebagai pelukis, tentu tidak hanya memotret asal-asalan. Ia memiliki kepiawaian dalam menggali ide, mengomposisikan objek, dan memberi suara dalam objek yang difotonya. Sejumlah foto Dullah ini dapat diangkat sebagai sebuah fenomena penting di sela kerja para pewarta foto sebelumnya. Dullah memang bukan jurnalis, tetapi ilmu komunikasi yang dipelajari secara mandiri menyebabkan karya-karyanya penuh makna dan mengandung sejarah yang berkualitas.

Sebagai penutup, penulis menyarankan agar foto-foto ini dapat menjadi bagian dari pelajaran hidup, pengetahuan yang luas, maka perlu disosialisasikan secara gencar. Foto-foto 
dokumenter ini bukan saja penting untuk dan karena dibuat oleh Dullah, pelukis ternama Indonesia, tetapi juga karena menyimpan sejarah bagi republik ini. Sebab, penciptaan karya foto dokumenter dalam dunia fotografi sesungguhnya berkembang seiring dengan kemajuan dunia fotografi itu sendiri (Setiyanto \& Irwandi, 2017:29). Dengan demikian, jika foto-foto ini lestari, baik bagi peneliti, penyuka fotografi, maupun calon pemimpin masa depan dari seluruh dunia dapat belajar dari fotografi Dullah ini.

\section{UCAPAN TERIMA KASIH}

Keluarga Dullah

Museum Dullah

Eka Putra Bhuana

Guruh Sukarnoputra

Empu Ageng Oscar Motuloh

Yayasan Bung Karno

Sigit Hendro Sutjahjo

Dicti Art Laboratory

\section{KEPUSTAKAAN}

Dhakidae, D. (2013). "Soekarno: Memeriksa Sisisisi Hidup Putra Sang Fajar." Majalah Prisma Edisi Khusus, Vol. 32, No. 2 dan No. 3.

Dullah. (1982). "BUNG KARNO Pemimpin, Presiden, Seniman (Dari kumpulan suratsurat pelukis Dullah kepada isterinya: Biby Fatimah." Harian Minggu Merdeka.

Flusser, V. (2000). Towards a Philosophy of Photography. London: Reaktion Books.

Ismanto, I. (2018). "Budaya Selfie Masyarakat Urban Kajian Estetika Fotografi, Cyber Culture, dan Semiotika Visual." REKAM: Jurnal Fotografi, Televisi, dan Animasi, 14(1), 67-76.

Kress, G., \& Leeuwen, T. van. (2006). Reading Image: The Grammar of Visual Design (Second Edi). New York: Routledge.

Motuloh, O., \& Surjoatmodjo, Y. (2013). IPPHOS Remastered. Jakarta: Galeri Foto Jurnalistik Antara.

Rusli, E. (2018). "Citra dan Tanda Malioboro dalam Konstruksi Fotografi." REKAM: Jurnal Fotografi, Televisi, dan Animasi,14(1), 1-15.

Sawega, A. M. (n.d.). "Dullah, Pelukis Istana: Mumpung Masih Ada Waktu, Kebutlah." Kompas.

Setiyanto, P. W., \& Irwandi. (2017). "Foto Dokumenter Bengkel Andong Mbah Musiran: Penerapan dan Tinjauan Metode EDFAT dalam Penciptaan Karya." REKAM: Jurnal
Fotografi, Televisi, dan Animasi, 13(1), 29-40. Sudarmaji. (1988). DULLAH, Raja Realisme Indonesia. Bali: Sanggar Pejeng.

Sukarnoputra, G. (2019). Wawancara dilakukan melalui Whattapps pada 13 Oktober 2019, pukul 11.01-15.31 WIB.

Susanto, M. (2014). Bung Karno Kolektor \& Patron Seni Rupa Indonesia. Yogyakarta: Dicti Art Laboratory \& Agung Tobing.

Susanto, M. (2019). BUNG KARNO Pemimpin, Presiden, Seniman. Yogyakarta: Dicti Art Laboratory dan Museum Dullah.

Yayasan_Idayu. (1984). Bung Karno Sebuah Bibliografi. Jakarta: Yayasan Idayu.

\section{Audio/Video}

Dullah. 1990. "Dullah, Raja Realisme". Dokumentasi Keluarga.

Video "Dullah: Raja Realisme Indonesia”, (1987). Film Dokumentasi Keluarga. Museum Dullah Solo. 